\title{
The Comparative Analysis of Kazakh and Polish Dramatic Works
}

\section{Boken Gulnaz Sailaubaikyzy, ${ }^{+*}$ Kabyken Magzhan Alibiuly' and Shapauov Alibi Kabykenovich ${ }^{\top}$}

\section{Abstract}

The article compares the dramatic works of the famous writers Slawomir Mrozek, Tadeusz Rozewicz and Sadykbek Adambekov, Kaltay Mukhamedzhanov in the aspect of Kazakh-Polish literary ties that have had a long history. The analysis is conducted taking into account the sociopolitical situation, which was formed in the 1960s-1980s and found its reflection in the plays written by these authors.

The authors emphasise that the influence of historical and social problems on the personality, moral-humanistic principles, etc. are interpreted not only by the course of action of the drama (conflicts of characters) but implemented by the psychology of the characters. The role of the characters' language is taken into account, the similarity and difference in the thematic, artisticideological, compositional, and plot structure of the plays of Kazakh and Polish playwrights are determined, and their artistic skills in creating the system of images are identified.

Separate provisions of the article are reasoned by the conclusions and statements of well-known Anglo-American, Polish, Russian and Kazakh scientists, which can be found in their scientifictheoretical and scientific-methodical works concerning the problems of the study of artistic ties in the history of world literature.

Keywords: Turco-European Cultural-Spiritual Ties, Kazakh-Polish Literary Ties, National Mentality, Sadykbek Adambekov, Kaltay Mukhamedzhanov, Slawomir Mrozek, Tadeusz Rozewicz, Conflict, Plot, Composition, Kazakh and Polish Playwrights.

\footnotetext{
${ }^{\dagger}$ Kokshetau State University named after Sh. Ualikhanov, Kazakhstan, 020000, Kokshetau, st. Abay, 76.

${ }^{*}$ Corresponding Author, Email: gulnazboken@mail.ru

'L.N. Gumilyov Eurasian National University, Kazakhstan, 010008, Astana, Satpayev Str., 2.

${ }^{\top}$ Kokshetau State University named after Sh. Ualikhanov, Kazakhstan, 020000, Kokshetau, st. Abay, 76.

(C)2018 Boken et al. 2018. This is an Open Access article distributed under the terms of the Creative Commons Attribution License (http://creativecommons.org/licenses/by/2.0), which permits unrestricted use, distribution, and reproduction in any medium, provided the original work is properly cited.
} 


\section{Introduction}

It is known that literary ties are based on the interrelation between the literature of a particular nation and the research of other peoples of the world. Like other phenomena and processes, literary ties have their historical stages and ways of development. These phenomena are most often based on historical ties of peoples, political-economic and cultural relations of the creators of works of art.

The fundamental works of scientists, who studied scientific-methodological foundations of the theory of literary ties, include the studies conducted by Pfister Manfred (1991, p. 23), M. de Ghelderode (1979, p. 39), V. Zhirmunskii (1979a, b, p. 79), M. Fetisov (1956, p. 112), H. Block (1963, p. 49), N. Konrad (1957, p. 73), G. Wellwarth (1986, p. 53), A. Kesteren (1975, p. 35), Sh. Satpaeva (1988, p. 27), M. Kirchner (1992, p. 36), R. Nurgali (2001, p. 19), G. Aqtay (2015, p. 427), A. Mayemirov (2015, p. 201), M. Madanova (1999, p. 21), E. Soltanaeva (2009, p. 47), A. Shapauov (2014, p. 206), K. Khalykov (2015, p. 44), S. Jennings (2009, p. 380), B. Nogerbek (2010, p. 58), B. Nurpeis (2013, p. $65)$, S.-S. Maftei (2013, p. 86) and many others.

In the history of the Kazakh cultural heritage, the beginning of the Kazakh-Polish spiritualliterary ties coincides with the period of resettlement of the Poles, who fought for the independence of the Polish people, to Siberia and the Kazakh steppe by the decree of the tsarist government of Russia in the 19th century. They left a great legacy: collections of folk songs and poems, scientific works devoted to the study of the richness of the Kazakh steppe and the beauty of nature, paintings and drawings about the life and lifestyle of Kazakhs, memories, engineering structures, architecture and maps of cities. All this reflected the industrious, free spirit of the Kazakh people, who respect their national language and traditions.

Abai Kunanbayev was the first Kazakh poet who understood deeply the spirit world of the Polish people, and in 1862, he translated into the Kazakh language the works of Adam Mickiewicz. Since acquiring independence in
1991, Kazakhstan has established strong political and economic, socio-cultural, and international relations with Poland, but literary and spiritual ties have been developing slowly.

In this regard, noting that the spiritual relationships between the two peoples have a historical basis, G. Aqtay, Doctor of Adam Mickiewicz Poznan University of the Polish Republic, writes:

[d]espite the fact that there are several thousand kilometres between the two countries - Kazakhstan and Lekhistan, there are many opportunities to strengthen cultural, literary, spiritual ties. Going back even further, already in the nineteenth century the prominent figures of the Polish people, its citizens contributed to the development of ties between the two peoples, paved their first ways (Aqtay, G., 2015, p. 427).

Some representatives of the Polish people were convicted and sentenced for long periods for their participation in the national liberation movement; others were in the service in the era of tsarist Russia, and still, others left an indelible mark on history with their scientific and artistic research. Travelers such as Adolf Yanushkevich (1803-1857), Gustav Zelinsky (1809-1881), A. Zaleski (1819-1880), Gross Severyn (1857, the year of death is unknown), Jan Vitort (1853-1903), Alexander Zataevich (1869-1936) left a rich heritage; they contributed to the rapprochement of the two countries by their conscientious work (Aqtay, G., 2015, p. 427).

The study of the interaction of Kazakh and Polish peoples, historical, cultural, political, literary ties positively influences the development of comparative literary studies. Thus far, Kazakh-Polish literary ties, including the dramatic genres, have not been examined and assessed theoretically and practically in an evidence-based way. Therefore, this work is one of the first attempts to fill this gap and make a possible contribution to the study of Kazakh-Polish literary connections. 
As an object of the study, the plays of Polish drama masters - the founder of "The Theater of the Absurd", Slawomir Mrozek, Tadeusz Ruzhevich, and the comedies of Kazakh playwrights Sadikbek Adambekov, Kaltay Mukhamedzhanov have been deployed.

Slawomir Mrozek is a Polish writer, playwright, essayist, and artist. His grotesque and satirical, absurd, parody stories and plays "The Police", "The Turkey", "Tango", "The Emigrants", "The ambassador", "The Portrait", "The contract" deride historical and cultural myths, stereotypes of demagogic thinking.

Tadeusz Rozewicz is a Polish writer, poet, playwright. His poems (collection "Anxiety", 1947, etc.), poems and stories, are devoted to the moral and philosophical problems of the modern age. In the anti-war and social dramas "The Card Index", "The Witnesses", "On All Fours", "The Trap", etc., he used grotesque, absurd situations and methods of literary parody.

Sadykbek Adambekov is a Kazakh playwright. $\mathrm{He}$ is the author of satirical comedies "Death of Ayubai", "Conflict of Shokbike", "Snake on a Golden Saucer", "Stars of Our House", "Fourth Fight", "The End of the General", "Light and Shadow" and the first Kazakh satirical novel "The Legend of the Shoot Girl."

Kaltai Mukhamedzhanov is a Kazakh playwright, publicist, screenwriter, professional theater critic. His plays "Ascension to Fujiyama" (together with the writer Chingiz Aitmatov), "The Wolf Under the Hat", "So I Need", "The Matchmakers Have Come", "The Roast is Ready", "In Foreign Countries", "We are not Angels" are well-known. He is the author of literary screenplays "Chinara on a Rock" and "Aiman - Sholpan".

The article begins with a description of the methods deployed to study this research. A discussion of results follows this.

\section{Methods}

The system-structural, historical-typological, and comparative methods have been used in the study. The system-structural method allowed us to conduct a compositional analysis of dramatic texts, considering the storyline, a gallery of images and the structure of the content of the plays. Scientific-theoretical and methodological works of scientists were used to determine the genesis of political situations, the influence of historical-social problems on human personality, and moral-humanistic principles. The comparative method was used to reveal the ideological-thematic, plot, and artistic-compositional similarity and distinction of Kazakh-Polish dramatic works.

The method of comparative research creates opportunities for revealing the general rules of the art of speech, facilitates the disclosure of general trends in the artistic process, as well as allows regarding literature as a single organism. The development of spiritual discourse is possible based on the historical-typological and comparative cultural relations. This contributes not only to the establishment of genealogical links and the disclosure of general trends in literature but also develops historical, ideological and psychological relationships.

\section{Results}

During the study of dramatic works of Polish and Kazakh authors, we managed to:

- determine the generality of dramatic situations, heroes' temper;

- identify differences and similarities in the conflicts of heroes;

- show the mastery of playwrights in creating typical images;

- establish a link between historical truth and artistic fiction in Kazakh and Polish dramatic works, a link between continuity of traditions and innovation;

- make a comparison from the textuality of the staged works;

- consider the dramatic process in the socio-cultural and socio-political context.

\section{Discussion}

In addition to the geographical distance between Kazakhstan and Poland, it is known that Kazakh belongs to the group of Turkic languages, while Polish belongs to the Western 
Slavic languages. However, literary ties between the two countries are developed due to political and historical relations, spiritual priorities and mental similarity of Kazakh and Polish peoples, as well as to the choice of close figurative-poetic approaches. This statement can be reinforced by the following opinion of an academician Konrad:

Literary ties are a historical category. When the peoples of the world were largely disunited, literary relations were established between geographically and culturally close countries that were at the same stage of historical development ... then the ties were maintained at a regional scale. In the development of broad international relations covering all the peoples of the world, cultural and literary ties are already becoming worldwide, turning to one of the forms of international communication (Konrad, 1966, p. 17)

The study and assimilation of artistic values that have developed in national literature play an important role in the cultural exchange. This will contribute to the formation of moral conclusions, active interaction, spiritual fulfilment and rapprochement of Kazakh peoples. The academician N. Konrad says that as these relations develop, they gradually "become one of the forms of international communication" (Konrad, 1966, p. 17), in the process of which new qualities and values arise as a result of creative interactions and positively influence the development of any literature. According to E. Soltanaeva, "these processes affect the geographical and historical and genealogical issues of the literature of far Europe and the countries of the East" (Soltanaeva, 2009, p. 3).

The analysis of the fiction works allows us to identify some common features of the Polish and Kazakh people. In our opinion, these features are the cult of honour and dignity, love and respect to parents; respectful attitude to popular rites, traditions and holidays, the openness of character, the will to live and others.
Any writer can use the events that took place in history, in society as a basis of her/his works. This is evidenced by the statement of a scholar known as $\mathrm{D}$. Al, who commented:

A hero of a dramatic work is always a son of his time and, in that respect, the choice of a hero for a dramatic work is also historical in nature, historical and social circumstances determine it. (Al, 2013, p. 288).

This statement signals that the vitality of works that have arisen in a historical-social situation is measured by the sincerity and reality of the author's images.

In another play entitled "Portrait" by S. Mrozek is a work that reveals an attitude of the Poles towards Stalinism. A dissident, a communist, who betrayed his friend, is the main hero of the play. They met many years later and spoke frankly. At the initial stage of our analysis of the drama, we considered them as friends, but further, during the drama, we understood that Anatole is not a friend of the main hero Bartodius, but his conscience. This is evidenced by the following Anatole's words: "Play chess with your own conscience ..." (Mrozek, 1990, p. 13).

From the dialogue of two former friends, we learn that in the regime of a totalitarian political system and extensive surveillance, a person, thinking only of himself, can even commit betrayal, lose his honour and dignity and then seek excuses before his conscience:

Bartodius: No, I did it not for my career.

Anatole: But, in fact, this combined somehow, didn't it? One with another. Your love has paid for itself.

Bartodius: I really loved him!

Anatole: And that is why you snitched on your best friend? (Pause) Moreover, it worked out so well that he would never know who finished him off. Denunciation was so accurate. (Pause) You condemned him to death (Mrozek, 1990, p. 18). 
Bartodius traded his best friend in for Stalin's portrait, for the Soviet communist government, which he sincerely loved. In the end, he remains alone, without friends and subsequently regrets this:

Bartodius. Yes, I am a small loner with a large portrait on the wall. It seemed to me that $\mathrm{He}$, the leader of the whole world, would connect me with the whole world, that, looking at his portrait, I would see the living world. It's an illusion, of course. It was just a portrait (Mrozek, 1990, p. 23).

In a similar situation, where a person commits treason, betrayal, can be found in the dialogue of the heroes of the satirical comedy of the Kazakh writer S. Adambekov "Shokbike's Conflict" - Tankybai and Tuman. The comedy tells us about cynical and vile actions of a political activist of the Soviet power Tankybai.

Tuman. How many innocent people are there in your bloody eyes? Do you know? Think about it! Who set me up? Huh? ... You are trapped! Soviet justice, justice triumphed ... They will ask you for the innocent years spent, for the youth burned in flames. Stop, you scoundrel, they will now be public prosecutors.

Tankybai (he laughs aloud, not showing fear): Tuman, what are you talking about? Oh, my God, you're still a child. No, sorry, Comrade Colonel, he escaped punishment. I apologised so many times since then (friendly). Everything is forgotten after the holiday, my friend! (Adambekov, 1989, p. 11).

At the same time, Kazakh and Polish writers do not propagate naked humanism, but carry it to the readers in the dialogues of their heroes, who admit their guilt, repent and answer before their conscience. If some people do not regret anything, others still want to justify their crimes.

Ultimately, the shortcomings of the heroes of works are found in every society at any time. Playwrights-writers masterfully expressed this not only in words but also through acts and deeds of their heroes, which is one of the main tasks of a dramatic work. B. Brecht believes that:

[A] dramatic situation is a conflict, in which a person or several people face a new problem, for which they have no ready-made solutions. Dramatism lies in the fact that an important moral issue is solved not in conversations, but in real destinies (Brecht, 1965, p.499).

Actions in the drama, unlike other types of literature, reflect the inner world, the world outlook and the psychology of heroes to a higher degree. Therefore, in a dramatic work every word, thought, feeling, attitude, action and inaction are in close interconnection. "A person in a play is revealed only in a dramatic fight, in a conflict, and, therefore, a conflict is inconceivable without the creation of aesthetically defined, internally effective characters" (Gorbunov, 1960, p. 16).

Besides, the drama is not created only in the discussions of heroes or in their relationships. This is mainly because of the contradictions in views and characters, subjective opinions that cause conflicts, the relationship between heroes' changes. As V. Belinsky writes:

Drama arises when persons in dispute, wanting to prevail over each other, try to point out to any aspects of the character of each other or tug on weak heartstrings and when their characters are expressed in the dispute through this, and the end of the dispute changes their relationship/ (Belinsky, 1999, p. 61)

Consequently, the main aesthetic drama categories - characters and actions, the behaviour of heroes - must be considered in the unity of the idea of the work with specific events. For example, in the play of the Kazakh playwright K. Mukhamedzhanov titled "The Wolf Cub Under the Cap", a young man Sapar, a literate and well-cultured person, who dreams of living in the city and making a career, deceives his pregnant wife Raushan (who waits 
for him day and night in the village), and decides to marry a beautiful city girl - Zhamilya. Marriage to the honest and trustful city girl, due to whom he could make a career, is meanness, betrayal, the fall of human morals. We learn about this from the thoughts of Sapar, who received a letter from home:

No, Sapar, be decisive! ... Frankly speaking, not only you, but mediocre writers, actors and even academicians get divorced and marry two-three times. This is the law of life. Postgraduate study tomorrow! Candidate, Doctor! What awaits me in my previous life! And Raushan is pregnant, even if she is four times pregnant, what can she give to my spiritual world? When I got married, she was a kolkhoz accountant; nothing has changed so far: she is still an accountant. And what about Sapar? No... Now Sapar needs Zhamilya; she is literate and well-cultured. Moreover, her father is an influential person in Almaty; I can achieve a lot with his help (Mukhamedzhanov, 1989, p. 17).

In this case, Sapar's act is similar to the behaviour of an oculist from a play of the Polish playwright, S. Mrozek of "Karol". The oculist said:

All the same, he had an incurable case of corneal exfoliation. To be honest, the fall could accelerate the disease progression. But who will guarantee that tomorrow he would not fall down the stairs, and the cornea would not exfoliate thoroughly? Anyway, it was impossible to help him (pause). Besides, he might not have come. He was not appointed for today. I also risked (pause). And although he is shortsighted, but still alive (Mrozek, 2001, p. 19).

While an envious person, a liar and a hypocrite Sapar step over his conscience and honour, not having compassion even on his innocent baby, the oculist will betray anyone for his own benefit, justifying himself and putting the blame on the incurable disease. And if, on the one hand, the behaviour of the heroes makes us laugh sarcastically, then, on the other hand, we understand that in real life one can meet such people and this makes us scared.

Laughter is one of the main means of comedy. It is achieved through humorous episodes, jokes, by ridiculing shortcomings, human vices, and satire. Therefore, bitter laughter is called satire, light jokes - humour. World literature classic authors B. Shou, L. Aragon, M. Auezov, V. Belinsky, N. Gogol, showed in their works that laughter could be a powerful weapon of struggle for justice. Shortcomings in people's lives and in society as a whole can be an object of laughter. N. Gogol notes: "A person who fears nothing in life can only fear laughter" (Gogol, 1956, p. 116).

Therefore, the aim of the comedy is to uncover and ridicule human vices, to address shortcomings, so that in the life such phenomena were as little as possible. Defending high moral values, laughter should educate society.

Formalism in society is also strongly criticised by a Polish playwright S. Mrozek in his play "The Police". The play begins with the release of the last convict, who spent ten years in prison. The criminal, after completing his time in prison, did not want to put his signature on the receipt, where he promised "to serve his country honestly after his release from prison", but suddenly he changed his mind and signed, which upset the prison governor. The fact is that now the prison is empty and it will have to be closed. And if the prison is closed, the police will be left without work. Understanding this, the prison governor is in no haste to let him go; he begins to ask the tricky convict questions to confuse and catch him in some evil intent. He even started to show photos of the Infanta and his brother Regent in order to make him angry, set the former criminal off and hear insults directed at the monarchs. However, it did not come off, and when getting out of the prison the convict said to the prison governor with a grin: 
I congratulate you from the bottom of my heart. The last conspirator died. A new subject was born. If I were you, I would have ordered to shoot out mortars and give my people three days off. However, what days off? From now on they are out of work... (Mrozek, 2001, p. 23).

As a result, the justice employees, because of the fear of losing their jobs, violated the law and turned into criminals. Of course, the reading of these two plays provokes laughter at the beginning. But then the reader realises that these absurd situations may easily take place in society, and it starts to frighten the reader.

Both authors in their plays criticise people, who care only about their careers and personal gain and leave no stone unturned in this way.

In this regard, speaking of the importance of dramatic works in society, B. Ismagulova notes:

Drama by its very nature reveals especially acute conflicts worrying the society and causing both high and low feelings (as opposed to poetry); while in drama there is no ready-made chain of reasoning about the cause and effect (as opposed to prose): the viewer/reader is provided with an opportunity to reflect and draw conclusions (Ismagulova, 2006, p. 12)

In the drama of S. Mrozek "Slaughterhouse", an ordinary violinist talks about his fate with a revived sculpture of Paganini.

Being a man is already very much", says Paganini about the happiness of being a man. But an ordinary violinist dreams of being famous, a great maestro and comes into dispute: "So what if I'm a man? Everyone. Being a man is not enough for me. I want to be something more; I want to be an outstanding person ... A genius. Unique and inimitable. What's the point of being a man, a performing artist? (Mrozek, 1991, p. 316).
However, Paganini warns that celebrity, success, titles, money, power, women, beautiful life - everything passes. Everyone who pursues all this will not be truly happy. Wrapped in pride and flattering words, you will not notice how the life will pass. Paganini says:

... You gradually become a slave of your art, and it demands more and more of you. You were not satisfied with your life before, and now, as punishment, your art is not satisfied with you. You beaver away, but you cannot keep up. Meanwhile, without noticing, you've already made a career. You have everything you needed: fame, money, women. But you cannot use all of this, because art absorbed you ... Before you know it, you have become a piece of marble (Mrozek, 1991, p. 318).

The author condemns people, who swap their lives for art without understanding the meaning of life, devote it to popularity, pursue the only glory. However, the violinist's dream came true, and he chooses the fate of a maestro. But, as Paganini warned, his fame did not make him happy. The head of the Philharmonic Hall united the territory of the concert building and the place for livestock slaughter, calling it the Philharmonic Hall of Instinct. Further, he suggested that the maestro be a slaughterer.

The maestro agreed, but on the day of his "debut", he committed suicide. He realised that there is no difference between the life and art since there is only a choice between the life and art, there is also a choice between the death and art. "The death of art, the death of culture lead to the death of mankind", - says the author in the finale.

In the satirical comedy "Golden Knife" by S. Adambekov, the negative social phenomena of the society are exposed: bribery, corruption, cunning and greed, which are beyond the human mind. The journalist A. Eleuov was imprisoned without charge or trial, because he wrote to the regional administration about troubles of ordinary people, that everybody, starting from the kolkhoz chairman, the district 
people's judge, the chief accountant and ending with the agronomist and the foreman of the horticultural brigade, "sucks blood" of them, like leeches.

The reporter was accused of the damage that his horse had caused to the kolkhoz by eating the vineyard, although he never had a horse. From the interrogation:

Omarov: The fact that the horse was in the vineyard is true. Because it came, snorted and made noise...

Aleuov: Should all the horses, snorting and making noise, be mine?

Omarov: How do I know? It was dark, but the horse was snorting and making noise. Certainly, it's yours (Adambekov, 1959, p. 9).

Or this one:

Musabayev: Citizen Aleuov, two horses from your personal farmstead, have grazed on the kolkhoz fields for one year. According to experts' calculations, they ate hay and drank water for the amount of 4,320 tenges. What is that supposed to mean?

Aleuov: Comrade Judge! This is slander, the essence of this slander lies deep. In my personal farmstead there was the only horse I bought from the collective farmer Murat in 1958, but then I sent it to the slaughter. The receipt is available (Adambekov, 1959, p. 13).

Certainly, we laugh at such foolish and empty accusations, but, on the other hand, we are outraged that such worthless bosses do not give rest to ordinary people.

A comedy of a Polish writer T. Rozewicz titled "Funny Old Man" begins with the end of a long trial of an old man, who slapped a little girl. The old man does not think he is guilty of something, on the contrary, he claims that in the street he was offended by small children, they put their tongues out at him. In the play:

These girls were few ... You won't believe, but they bothered me terribly... they chased me. All this was cunning. I did not even know how to protect myself from this. Previously everything was simpler: either a person took such a treasure on his knee and gave a child a couple of slaps on the bare bottom, or he went to the parents, and the matter was solved very quickly. But then again -by the hand ... I was even thinking about going to the house management committee, school, the police ... Finally, I went to a lawyer. I left his office in horror: he advised me to consult a psychiatrist. To tell you the truth, he impressed me as totally insane. He rubbed his hands all the time, blinked at me and made faces. One of those girls once told me that I should give her a canary. Together with the cage. I refused. And she looked at me so menacingly and left without words ... I was even frightened (Rozewicz, 1979, p. 19).

An obvious question may arise here: Is the author mocking the old man who is out of his mind? Is he laughing at him? But, reading this work further, we see the gloomy life of a lonely old man, who often feels down alone, but he takes offence neither at his life nor at people, although he does not understand and gets angry at children, who laugh at his appearance.

The human vices depicted in the play make us laugh turning into sarcasm. All the actions and events in the play should be depicted as if they take place in our life.

\section{Conclusion}

The scientific novelty consists of the comprehensive study of the thematic, plot, ideological, and compositional community of dramatic works of Polish and Kazakh authors. Proceeding from the above, there are many different similar themes in Kazakh and Polish comedies.

Although in dramas "Slaughterhouse", "Police", "Oculist", "Karol" by S. Mrozek and comedies "It Serves Me Right", "Wolf Cub under the Cap" by K. Mukhamedzhanov; there are ideological- 
thematic features, but there is a certain generality of the plot-compositional aspects. This is the story of a violinist who yearns for glory, dedicated himself to art and denied a conscious life for the sake of a false "poetic gift", about mercenary Khaidarbek.

In the comedies, "Funny Old Man" by T. Rozewicz and "Golden Knife" by S. Adambekov, the negative social phenomena of society are exposed: bribery, corruption, cunning and greed, which go beyond the human mind. Both writers give their opinion on the pressing problems of society with a light comic language, but it is obvious that their comedies conceal a complicated tragedy.

During the study, a complex analysis of dramatic works was conducted with the use of system-organisational, historical-typological and comparative methods, which can be used to study foreign literature and comparative linguistics.

\section{References}

Adambekov, S. (1959). Zolotoi nozh [Golden Knife]. Almaty: Kazakhskaya literatura.

Adambekov, S. (1989). Vorota Khodzhanasyra [The Gate of Khodzhanasyr]. Almaty: Pisatel. (p. 317).

Al, D. (2013). Osnovy dramaturgii: Uuchebnoe posobie [Fundamentals of playwriting: Textbook] (6th ed.). Sankt- Petersburg: San, Planeta muzyki. (p. 288).

Aqtay, G. (2015). Kazakhsko-polskie kulturnoliteraturnye svyazi [Kazakh-Polish cultural and literary ties]. In Ualikhanovskie chteniya-21: Materialy mezhdunarodnoi nauchnoi konferentsii, Kazakhstan, Kokshetau, 17-18 aprelya [Ualikhanov's readings-21: Materials of the international scientific conference, Kazakhstan, Kokshetau, 17-18 April] (Vol. 1, p. 427). Kokshetau.

Belinsky, V. (1999). Sochineniya $v$ trekh tomakh [Works in three volumes] (Vol. 2, p. 61). Moscow.
Block, H. (1963). Mallarme and the symbolist drama. Detroit: Wayne State University Press. (p. 211).

Brecht, B. (1965). Teatr [Theater] (Vol. 1, p. 499). Moscow.

de Ghelderode, M. (1979). Dramaturge et conteure: Actes de collogue francaispolonais. Wroclaw, Poland. (p. 287).

Fetisov, M. (1956). Literaturnye svyazi Rossii $i$ Kazakhstana [Literary links of Russia and Kazakhstan]. Moscow. (p. 346).

Gogol, N. (1956). Sobranie sochinenii [Collected works] (Vol. 6, p. 116). Moscow.

Gorbunov, E. (1960). Idei, konflikty, kharaktery [Ideas, conflicts, characters]. Moscow: Sovetskii pisatel. (p. 16).

Ismagulova, B. (2006). Khudozhestvennodramaturgicheskoe dvuyazychie: sotsiolingvisticheskii i psikholingvisticheskii aspekty: Avtoreferat dissertatsii na soiskanie uchenoy stepeni doktora filologicheskikh nauk [Artistic-dramatic bilingualism: Sociolinguistic and psycholinguistic aspects: PhD thesis abstract]. Almaty. (p. 12).

Jennings, S. (2009). Dramatherapy and social theatre: Necessary dialogues. Routledge. (p.38).

Khalykov, K. (2015). Theatre semiotics: The creation of meaning in scenography in the Kazakh drama theatre. Journal of Political Science KNU Series, Philosophy and Cultural Studies, 1(50), 44-51.

Kirchner, M. (1992). Kazakh and Karakalpak. In Johanson, L. \& Csató, É. Á. (Eds.), The Turkic Languages. London: Routledge. (pp. 318-332).

Konrad, N. I. (1957). K voprosu o literaturnykh svyazyakh [On literary links]. Izvestiya AN SSSR, 16(4), 304.

Konrad, N. (1966). Zapad i Vostok [West and East]. Moscow: Nauka. (p.337).

Madanova, M. (1999). Kazakhsko-frantsuzskie literaturnye svyazi XX veka i problemy 
sravnitelnogo literaturovedeniya:

Avtoreferat dissertatsii na soiskanie uchenoy stepeny doktora filologicheskikh nauk [Kazakh-French literary ties of the twentieth century and the problems of comparative literary studies: Doctoral thesis abstract]. Almaty. (p. 55).

Maftei, S.-S. (2013). Philosophy as 'artwork': Revisiting Nietzsche's idea of a 'philosophy' from the point of view of the 'artist'. Procedia: Social and Behavioral Sciences, 71, 86-94.

DOI:10.1016/j.sbspro.2013.01.012

Mayemirov, A., Khalykov, K., \& Nurpeis, B. (2015). Ethnic and cultural aspects in the development of Kazakh theatres during the Independence Period: The problems of human existence. Folklore, 62, 201-224. Retrieved 2 October 2017 from, www.folklore.ee/folklore

Mrozek, S. (1990). Khochu byt loshadyu: Satiricheskie rasskazy i pesy [Want to $\mathrm{Be}$ a Horse: Satirical stories and plays)]. Moscow: Molodaya gvardiya. (p.310).

Mrozek, S. (1991). Boinya [Slaughterhouse] (Shatalova, Z. Trans.). Moscow: Iskusstvo. (p. 321).

Mrozek, S. (2001). Karol [Karol]. In Testarium: Izbrannye pesy i proza [Testarium: Selected plays and prose] (Shatalova, Z. Trans.). Moscow: Art-Flex, Vakhazar, 2001. (p. 321)

Mrozek, S. (2001). Politsiya [Police]. In Testarium: Izbrannye pesy i proza [Testarium: Selected plays and prose]. Moscow: Art-Flex, Vakhazar. (p. 832).

Mukhamedzhanov, K. (1989). Izbrannye pesy [Selected plays]. Almaty: Pisatel. (p. 121).

Nogerbek, B. (2010). Folklore traditions in Kazakh cinematography. San'at: Journal of the Academy of Arts of Uzbekistan, 1, 5861. Retrieved 2 October 2017 from, http://sanat.orexca.com/2010/2010$1 /$ baury

Nurgali, R. (2001). Iskusstvo dramy [The art of drama]. Almaty: Pisatel. (p. 576).
Nurpeis, B. (2013). Kazakh theatrical tradition and succession of Eurasian culture. In Proceedings of world e-conferences on advances in science and technology, Amsterdam, Netherlands, June 12-13 (pp. 65-87).

Pfister, M. (1991). The theory and analysis of drama. Cambridge University Press. ( $p$. 339).

Rozewicz, T. (1979). Izbrannoe: Poemy, pesy, proza [Selected works: Poems, plays, prose]. Moscow: Khudozhestvennaya literatura. (p. 320).

Satpaeva, Sh. (1988). Literaturnye svyazi [Literary links]. Almaty: Nauka. (p. 253).

Soltanaeva, E. (2009). Kazakhsko-russkie literaturnye svyazi v kontse XX veka: Avtoreferat [Kazakh-Russian literary ties at the end of the twentieth century: Thesis abstract]. Almaty. (p. 3).

Shapauov, A. (2014). The history of development and investigation of Kazakh national drama. Life Science Journal, 11(6), 206-209.

van Kesteren, A. (1975). Moderne dramentheorie. Kronberg. (p. 124).

Wellwarth, G. (1986). Modern drama and the death of God. London. (p. 97).

Zhirmunskii, V. (1979a). Izbrannye trudy: Sravnitelnoe literaturovedenie: Vostok i Zapad [Selected works: Comparative literary studies: East and West]. Leningrad. (p. 138).

Zhirmunskii, V. (1979b). Sravnitelnoe literaturovedenie: Vostok i zapad [Comparative literary studies: East and West]. Moscow: Nauka. (p. 495). 